\title{
ENMESHING CLASS, GENDER, AND ETHNICITY OF "FAMILY" IN SELECTED FICTION BY WOMEN WRITERS
}

\author{
Sri Mulyani \\ Sanata Dharma University \\ Yogyakarta, Indonesia \\ srimulyani@usd.ac.id
}

\begin{abstract}
In a Marxist framework, class struggle is prioritized while gender struggle is only secondary. This debate on class over gender priority and vice versa has dominated Anglo-American critical scholarship. Meanwhile, in Asia, Mao Zedong claims that China's Cultural Revolution has freed women from both class and Confucian patriarchal domination. His claim, however, is far from the truth since Chinese women still have to fight for their equality. Likewise, there are still ongoing struggles for women's rights and equality in today's Western societies. This article argues that various revolutionary social changes in Eastern or Western contexts imply a hierarchical relation where women would fall into the bottom of the hierarchy. Women of different classes and ethnic backgrounds experience multiple subordinations differently under patriarchal domination. These multiple subjugations of women can also be seen in the smallest unit of society such as "family." However, at the same time, "family" can also become a locus of women's liberation from those oppressions. Henceforth, "family" can function as an arena of power struggles. This article argues that women's experiences and struggles against patriarchal and capitalist oppressions are deeply entangled with their class, gender, and ethnicity. Moreover, the very same class, gender, and ethnic groups also create further divisions that ultimately bring women to the lowest rank and under different forms of subordinations, as portrayed in the selected women writers' fiction in this article.
\end{abstract}

\section{Keywords}

minority literature, feminist aesthetics, intersectionality, patriarchy, capitalism 


\begin{abstract}
About the Author
Sri Mulyani is a lecturer and researcher at the English Department of Sanata Dharma University, Yogyakarta, Indonesia. She earned her B.A. in English from Sebelas Maret University, Surakarta; her M.A. in American Studies from the University of South Florida, Tampa, under a Fulbright scholarship; and her PhD in English Language and Literature from Ateneo de Manila University under a UBCHEA scholarship. Her research interests are gender and minority groups in language and literature. Her book Revisiting Race, Class, and Gender in Language and Literature will be launched in 2020 featuring the compilation of her early research as a junior lecturer in 1993 to her recent works as a senior researcher in the 2000 s.
\end{abstract}

Kritika Kultura 35 (2020): 45-071

(c) Ateneo de Manila University

<http://journals.ateneo.edu/ojs/kk/> 
Marxist feminist commitment to class struggle is followed by the concern for gender struggle. Marxist feminists argue that gender division is crucial in theorizing class conflicts because class analysis only is not adequate. Class and gender concerns need to be tackled mutually to understand the class and gender divisions in the household and public sphere (Robinson; Sargent; Hartmann). Family is the place where gender and class are established. Engels shows that "the first division of labour is that between man and woman for child breeding" (Engels 106-7) and "Only by analogy can a class description be applied to the family, in which, because of their respective relations to production, the husband is the bourgeois whereas his wife represents the proletariat" (106-7; Robinson 106). Class and gender are interrelated; class relation is gendered and gender relation is also hierarchical. Class defines the experience of women, and women's experience also informs the meaning of class. Acker argues that "class is constructed through gender and class is always gendered" (145). Pollert employs complex metaphors like "enmesh," "intertwined," and "infuse" to describe the interconnectedness of class and gender (1996). The title of this article borrows Pollert's view to display the intricate interrelatedness of class and gender. In addition to class and gender, ethnicity is crucial to contextualize women's experience under patriarchy and capitalism. Therefore, this article also attempts to analyze gender, class, and ethnicity interplay in the "family" as simultaneous forces. The construction of gender, class, ethnicity, and the family as forces can be closely studied through Foucault's perspective of knowledge and power connection, particularly in the way the patriarchal discourse controls knowledge and dictates meaning in gender relations to marginalize women. Foucault's theories are useful to locate and identify the site of women's oppression by the systematic patriarchal discourse and also strategic to uncover how "woman" in the family is constructed as the product of systems of social relationships. Today many feminist scholars no longer see gender as an isolated category; Acker and Pollert, for example, appropriate relevant perspectives from Engels and Foucault to theorize the intersecionality of gender, social class, and power relation.

As observed by Engels, the first division of labor between woman and man is established in the family; thus, family becomes the important locus to define class and gender. Accordingly, family theorizing is very important in feminist scholarship. Therefore, by employing a feminist framework that pays close attention to the interrelationship of class, gender, and ethnicity, this article analyzes "No Wine in His Cart" (1940, 1966, and 1989), a short story by the American writer Meridel Le Sueur, and Fistful of Colours (1992 and 2003), a novel by the Singaporean-Malaysian writer Suchen Christine Lim, to scrutinize the gender and class struggles in the "family." In terms of genre, both selected works are narrative prose, although one is shorter than the other in length. The short story, because of its brevity, focuses more on a single event and its unity of effect as famously theorized by Edgar Allan Poe; meanwhile, an event in a novel is only a small part of various events. 
However, despite their differences in length, there are some reasons for selecting these narratives from these two writers. Firstly, both the short story and novel are considered to be very important genres in feminist writing. In Western literary tradition, the short story is also employed by feminist writers such as Virginia Woolf to articulate the voice of the oppressed and marginalized members of the society as a form of "poverty" empowerment (Reynier 6). Similarly, in its conception, a fictional novel or xiaoshuo in Chinese literary tradition is also seen as an "inferior" genre that focuses on the lives of marginalized groups, the gossip-like stories of families, women, and small men; yet it has a dissenting quality to rebel against the ruling power ( $\mathrm{Gu} 5,22-24)$. Interestingly, in Western literary tradition, the novel is also seen to revolve around the "world of mothers" (Bakhtin 15) and it "valorizes events from the everyday world of mothers" (Donovan 4). As a "feminine" genre it also has the quality that "opposes the official, the public, the 'masculine' and the governing, and speaks for the marginal, the dispossessed, the emotional" (Doody 366). Thus, I believe that both Le Sueur and Lim are conscious of their selected genre as both aesthetic and ideological strategies. As women writers, both Le Sueur and Lim experience social, political, and literary challenges because of their ideology and commitment to write the stories of the marginalized group. Because of her leftist leaning, Le Sueur's literary legacy is almost non-existent in the American literary heritage, although she is an important literary figure of the 1930 (Lauret 11-44). Meanwhile, Lim also faces censorship because she wants to dedicate her writings to voice the "stories of the unsung, unsaid and uncelebrated in Singapore" (2007). Secondly, their two works are selected because both works depict genderclass struggle in the "family"; both works also narrate the marriage of men and women from different classes that lead to class mobility and gender-class conflicts. Moreover, both works also present the heterogeneity and complexity of race, class, and gender in the "family." Finally, by selecting those two texts from two writers of different contexts, this article also attempts to demonstrate that in spite of different history and tradition, "family" is indeed crucial in the construction of gender roles and spheres and it also becomes an arena of gender and class power struggles both in the West and the East.

\section{THEORIZING “FAMILY”: GENDER, CLASS, AND ETHNICITY INTERPLAY}

Foucault's History of Sexuality (1978) and Power/Knowledge (1980) have explored how "knowledge and power" work and operate through representation and disclose the production of knowledge through "discourse." Similarly, drawing from Foucault's theory of representation, "family" can be seen as a discourse and a system of representation in which patriarchal discourse constructs and regulates knowledge and meaning. At the same time, "family" functions as a discourse that

Kritika Kultura 35 (2020): 47-071

(C) Ateneo de Manila University

<http://journals.ateneo.edu/ojs/kk/> 
perpetuates patriarchal values that define social-cultural-economical roles for men and women. Notions about "family" and its structures vary across different cultures and geographical settings. The term "family" itself has been used in various different meanings and perspectives, and in our societies, "family" has also undergone continuous evolution. In fact, historically, "family" has been theorized and debated about from different perspectives in anthropology, biology, philosophy, history, sociology, religions, politics, and the different schools of critical theories over different periods of time.

"Family" as a construct has undergone changes over time. Scholars have tried to understand the complex changes, and because of its complexity, experts often have to put "family" in quotation marks. In addition to the studies of "family" in terms of its nature, structure, and function, philosophers, scholars, and theorists have also formulated and debated certain theories and approaches to connect "family" and the society to different political positions and perspectives. Plato had written about women and family, Aristotle proposed the split of the public and private sphere, and various scholars proposed different views on the family as a social unit. Those theories and concepts of family have also explained and defined women and their roles in "family," but finally women themselves had articulated their voices to theorize "family" as well. Woman as a category, however, is not single but multiple and plural and even women who claim themselves to be feminists have different views and perspectives of "family."

Liberal feminists, for example, do not emphasize the women's role and place in "family" as an economic issue but instead give more attention on the changing gender roles. In this respect, liberal-feminist theories are more preoccupied with "the evolving nature of the family from a patriarchal structure to an egalitarian or democratic family structure" (Ollenburger and Moore 29). Meanwhile, the radical feminists view "family" as "an oppressive institution" and women themselves are viewed to have played a significant role in their own gender oppression. Radical feminists are highly critical of "family" not only as a patriarchal institution but also of its heterosexual normativity that excludes gays and lesbians in the familial structure and institution.

Meanwhile, the American critical theorists and feminists like Nancy Fraser and Linda Nicholson frequently problematize feminist issues into poststructuralist and postmodern contexts. Fraser and Nicholson, for instance, argue that "feminist theory must become postmodernist" so that the notion of "woman" is not viewed as unitary or universal but seen in terms of the dynamics of "class, race, ethnicity, age, and sexual orientation" in addition to gender difference (quoted in Sarup 158). This poststructural/postmodern feminist theory is pragmatic in its methods and practices, addressing specific concerns or issues at hand. Indeed, "family" and 
the history of "family" have evolved over time. Therefore, there have been many attempts to redefine "family" and to rethink "family" not in terms of its structure and stability, or its traditional portrayals, norms and standards but more in terms of its process and change to meet the contemporary social realities and problems.

One influential endeavor to redefine and rethink the notion of "family" has come from feminist perspectives. Feminist theories view gender as very basic and crucial to all social structures, institutions, and organizations; as such, feminist scholars have pointed out how "the family" and the ideology of "family" play a significant role in the persistence of patriarchal attitudes and norms (McDowell and Pringle 74). Feminisms challenge patriarchal and sexist notions and concepts about "family" because through "family," patriarchy defines the gender roles and limits women's spheres. As such, the home and "family" become the source of oppression and sexism where women experience gender inequality, oppression, and subordination.

Myra Marx Ferree, the American feminist and sociologist, has written numerous published works on gender inequalities in the family, sociological and political perspectives of gender, the relation of gender and private-public spheres. Ferree also attempts to debunk the myth that "the family is a private world" where women are the reigning queens with unlimited power and responsibility for the mental and physical welfares of all the family members, including the "prevention of male violence." Furthermore, Ferree aims to "redefine families as arenas of gender and generational struggles, crucibles of caring and conflict, where claims for an identity are rooted, and separateness and solidarity are continually created and contested" (quoted in Eshleman 68).

Similarly in Asia, particularly the Chinese contexts, numerous Chinese feminists have also challenged writers of the May Fourth Movement and redefined the notion of "family." Ding Ling, a vocal Chinese feminist of the May Fourth Movement, has frequently spoken out against the oppression of Chinese women in the Confucian family. As a Marxist feminist, Ding Ling writes her famous work, Muqin (Mother) (1933) to liberate her female characters from the oppressive Confucian system of feudal kinship and to encourage women to have more participation in the state and less in the "family" (Barlow 57). Ding Ling also views the Confucian patriarchal "family" as oppressive and "cannibalistic" toward women and presents the patriarchal family "as an evil second only to Japanese imperialism" (Barlow 204). In her early participation in the Chinese Marxist movement, she was convinced that the Communist Party of China would be able to liberate women from family oppression and to grant women more public space to participate in the party and the state. However, she finally encountered a bitter reality that class liberation in 
China had not yet succeeded to liberate women from gender oppression in both the family and the state.

Historically, the Chinese family known as the jia (家) is a bound group of kin related by marriage, descent, or adoption (Lang; Evans; Cohen). The Chinese family practices vary from one region to another; however, they generally follow the Confucian values of age and gender deference from younger to older members and women to men. The Confucian Chinese family is patrilineal that includes all family members both the dead and the living intimately bound through one male ancestor observed continuously through ancestor worship. The presence of a male heir is crucial to perform the ancestor worship that is regarded as one of the most fundamental functions of the Confucian Chinese family; thus, the preference and demand of the male heir to continue the patriline is indispensable. Having a male progeny in the family is considered an act of outmost filial piety, that is, also one fundamental core of Confucian values. According to Confucius, filial piety is "the root of all virtue" (qtd. in Lang 10; Legge 466).

To ensure the survival and continuity of the Confucian Chinese patrilineal family, the membership of each member of the family is clearly defined, and as mentioned earlier, demanding submission and respect for the older and male members of the family. The Confucian endorsement to patriarchy is clearly seen in the way the Confucian conception of gender dictates women's role and place in the family. As famously articulated in the Confucian Three Obediences to govern women, as an unmarried woman (daughter) she must obey her father, as married woman (wife) she must obey her husband, and when her husband died as a widow she must obey her son (Zang 307-308; Stacey). There are many rules and values articulated in the Confucian discourse on family to enforce the Chinese family's patrilineal and patriarchal orientation.

Historically, Chinese cultural and ritual texts link patrilineality to civilization. The famous Confucian text of the ritual tradition, the I-li (Book of Rites) states that animals know their mothers only but not their fathers. The same thing goes with "People of low social status." Such people do not have the knowledge about the "importance of knowing who father and mother are," therefore, accordingly, the higher social status and civilized, the longer line of ancestors people have, and thus, they will "acknowledge and hence worship" (Waltner 69).

Similarly, Chuang-tzu, the Taoist text, expresses a similarly shared perspective. The text explains, "In the age of the legendary ruler Shen-nung, people knew their mother and not their father." Likewise, other important texts, Spring and Autumn Annals of Mr. Lu and Book of the Lord of Shang, post similar ideas. Furthermore, the two texts show that such absent distinctions between men and women will lead to 
the absence of ruler and hierarchy. Those classic sources show the interweaving of gender, civilization, and politics. Thus, in such a view, it is understood that "before there were gender distinctions and recognized paternity, political order was not possible" (Waltner 69). To maintain this civilized and political order, paternity and the patriline require the transmission of surnames that is "from father to child. The surname was a permanent marker of membership in one's paternal family" (Waltner 69). These two different historical and contextual views of theorizing "family" from feminist standpoints are employed to analyze the selected works in this essay: the Eastern contexts for Lim's Fistful of Colours and the Western contexts for Le Sueur's "No Wine in His Cart."

\section{GENDER STRUGGLE AND CLASS WAR IN LE SUEUR'S “NO WINE IN HIS CART”}

American Leftist writer Meridel Le Sueur was born on February 22, 1990, in Murray, Iowa, and raised by social and political activist parents. She herself then was also immersed in social and political rights of the American working class. She often uses Iowa and the life of Iowan working classes as the background of her works so that critics sometimes also regard her works as "regionalism" literature. She is also labeled as one of the "Red" writers for her political activism and Marxist leaning in both her life and works. Le Sueur is frequently compared to Tillie Olsen in their reputation as American working class writers who portray the struggles of American women during the Depression Era enduring poverty and political and gender oppression. Le Sueur's great commitment to articulating the lives of working class women is clearly seen in her short story "No Wine in His Cart," from her collected stories Salute to Spring (1989). She also considers her novel The Girl (1978) as a "memorial" for the working class women of the Great Depression. Besides prose, she also writes some collected poems in Rites of Ancient Ripening (1975). After getting blacklisted because of her Communist-leaning activism, Le Sueur in the later period of her life turned to writing some children books.

"No Wine in His Cart" (1940) is the life story of Stella, the daughter of working class parents, who marries into a prominent rich family. Despite having socially and financially settled into a comfortable family life on their big and luxurious homestead, it still cannot shield her from the struggles and difficult realities experienced by her parents' fellow working class, who are oppressed by her rich capitalist husband and family. Even the silence of the domestic helper in her household still constantly awakens her proletarian roots. She is deeply torn by her present social mobility and her proletarian sympathy that eventually drives her into madness as well as disgust/hatred toward her husband's body and social political domination. Le Sueur's works in general are dedicated to her leftist political view 
and commitment. Rather than preoccupying with Le Sueur's leftist agenda, this article pays more attention to the ways the story displays class and gender struggles. Home, marriage, and family become the locus of class and gender struggles in "No Wine in His Cart." The wife-husband relation is explicitly structured to resemble Engels' class analogy of the family: "the husband is the bourgeois whereas his wife represents the proletariat" (Engels 106-107; Robinson 106). The wife Stella is from a working-class family while the husband, Arnold Gregory, is the son of a wealthy family that manages the stock exchange.

Oh, Stella has made a good marriage, an excellent marriage, what a break for a girl like that, a Yale man, plenty of money. It was a break to marry money ... When she was lonely for the raucous, hand to mouth, terrible and yet abundant life of her parents she went down to the wine cart to look at all curious little painted men, the wide mouths, the workman's body like her father's. (Le Sueur 28-29)

By paternity, Stella is a member of the working class, the proletariat; by matrimony, she becomes the member of the wealthy class, the capitalist. This class upward mobility is exactly what her mother expects from her: "Her poor mother had wanted her to marry above her" (Le Sueur 34). Thus, Stella's class identity is always attached to her familial class status: the workingman's daughter and the bourgeois's wife. Therefore, the "man's class" is extended to his "woman": "women can acquire a class affiliation from their fathers or husbands and that this identity is functional ... Self-definition, for a woman, still means self-definition in relation to men" (Robinson 107 and 122). Accordingly, class and gender are coextensive, but gender becomes its auxiliary. In Stella's case, class identity can be both inherited and acquired through male status. Meanwhile, Arnold, Stella's husband, inherits not only his father's class status but also his father's capital and establishment because he is the son in the family: "the heir to the Gregory millions lay upstairs, about to have his dinner, but she didn't want to see him today" (Le Sueur 28).

The different gender and class roles and positions experienced by Stella in her "proletarian family" and Arnold in his "rich bourgeois family" can be seen as a product of patriarchal discourse in a Foucauldian concept that has dominated both "families" across class boundaries. In such case, Foucault's theory of representation, "family" as a discourse and a system of representation in which patriarchal discourse constructs and regulates knowledge and meaning is indeed very apparent. Therefore, in similar fashion, "family" functions as a discourse that perpetuates patriarchal values that define social-cultural-economical roles for men and women. Foucault's concept of discourse in this case is crucial for feminist perspectives to critically analyze the "family" discourse. Sara Mills as feminist scholar also admits that the feminists and feminist theories have also heavily borrowed from Foucault's work on discourse theory. Foucault does not focus his work or theory on women 
but his theory of discourse that emphasizes the discourse of power is indeed very useful in feminist critique; however, as generally known, feminist theories have had to modify and to transform Foucauldian theories to fit into a feminist framework. Hence, this study follows Foucauldian discursive theories that have been modified, appropriated, and integrated into feminist criticism, especially as deployed by Sara Mills and Judith Butler.

"Family" as a discursive construct is a system of representation. As such, it will not function and operate well without a continuity of practices and reproduction of behavior. John Gagnon and William Simon (262) approach family practices as "socially scripted behavior":

in order for families to exist, as practice and meaning, they must be acted out through performed roles of sex, coupling, caring, parenting within intimate relationships confirmed publicly by specific codes of behaviour. Familial scripts are internalized by family members so as to reproduce continuously the essence of familyness. In this sense, there has to be a continuing dialogue between families themselves and the public representations of them in constructing the meanings of familyness. (quoted in Chambers 27)

The reproduction of "family" as scripted behaviour that needs repeatedly to be performed can also be analyzed by utilizing Butler's theories of gender in her seminal work Gender Trouble: Feminism and the Subversion of Identity (1990). For Butler, sex and gender are performance, discursive practices that are repeatedly enacted to maintain its status as norms and regulatory ideals. "Family," too, needs to be repeatedly enacted to continue to function discursively. Sharing Foucault's constructivist perspectives, Butler also views discourse as a "normative regulatory power." Discourse also operates and functions to define and construct and produce "bodies as object of knowledge." Furthermore, from this perspective, "family" as a discursive construct is a "site" through which the sexed subject is produced, is familiarized as a "sexed" and "gendered," as well as "classed" subject is significant to offer a critical study on Le Sueur's "No Wine in His Cart."

The title of this short story itself has already demonstrated the notion of "family" as a scripted and performative behavior. The antique wine cart from Sicily, the luxurious become a display of Gregory family's social class status; and Stella as the wife of Arnold Gregory is given the right and privilege to enjoy it. However, when the gender and class conflicts intensify between them as husband versus wife as well as capitalist versus proletariat, Stella projects the Gregory family's social status symbol into her own social class and family roots by reversing and turning the symbol upside down. Stella imaginatively, almost psychotically attempts to turn the decorated paintings and pictures of the working men and women in the 
wine cart alive to attack the Gregory family as a call for revolution to destroy the capitalist. She thinks of "family" not only as biologically related. Thus, the title suggests a defeat for the capitalist Gregory family; the wine cart signals a start of the revolution to strip the Gregory family from their social class status symbol.

Interestingly, the class and gender struggles in this short story do not simply fall into the binary opposition of man versus woman and capitalist versus proletarian, but also complicate the struggles and disrupt the dichotomy by presenting the figure of Henrietta, the housekeeper. Henrietta functions both as affinity and difference to Stella's social class status. Both are from a poor working class family, but these two women no longer "share" class status and instead form a workeremployer relation. As Stella's servant, it is Henrietta who performs all of Stella's household work and burdens; this is possible because Stella's upward class mobility and rich husband can afford to pay wages. As a woman, Henrietta is capable of participating in "public" space to earn wages, yet her paid job is still under the "private" sphere and "domestic" duties of a person of the same gender, but from a more privileged class. Her doubly marginalized position as a woman from the lower class is portrayed in the way she becomes a housekeeper in Stella's wealthy household. Her waged job demands her to perform all of Stella's unwanted domestic duties yet she is only a worker and an outsider, as depicted in the story where she is frequently located "at the door" while serving her employer's family: "Stella looked at Henrietta, the housekeeper, who stood in the door . . . Henrietta stood in the doorway announcing supper" (Le Sueur 26 and 34). As a poor woman, Henrietta experiences both gender and class oppressions. She has to work long hours as a housekeeper, performing domestic services in the Gregory family to support her family financially, and still has to perform her gender roles and duties for her own family. In contrast to Stella's case, although she is originally from a working-class family but as a wife of a rich man, she has gained a higher social class status and financial security; however, her class mobility has not liberated her from gender oppression. Her husband always expects her to be an obedient and passive wife, and when she fails to meet his expectation, he always reminds her of her own class origin. Therefore, regardless of social class, women like Stella and Henrietta still have to encounter gender oppression in their family. Therefore, the class and gender relation is more complex and heterogeneous.

Unlike her husband's class status that is secure from generation to generation, Stella's class identities are complicated, conflicting, and flimsy. As a wife of a wealthy man, she lives in a luxurious house (the house is her wedding present) located on the top of the hill on the suburb surrounded by the tennis court, wine cellar, and artificial lake, with the services of a housekeeper, butler, gardener, and more. However, her acquired class privileges do not correspond to her class consciousness: she sympathizes with the working class more than the capitalist. 
When the "riot" strikes her husband's stock exchange establishment, the first thing that she is worried about is the safety of the workers instead of her husband. The insubstantiality of her class identities is visible whenever she has arguments with her husband, and he always brings the class difference into play.

\footnotetext{
He looked at her coldly, "You'd better go to your room," he said.

"I won't," she cried.

Then he said in a low cutting voice, "You'd be in that mess yourself if I hadn't married

"Yes," she said coldly. The room seemed to dissolve in worm-eaten wood. (Le Sueur 35)
} you."

Arnold reminds his wife of her class roots in their disagreement, and he identifies Stella with the women who join the strike. She would be just like one of those "poor and disgusting" women in the strike without her marriage to Arnold. He shows his class superiority and her class inferiority as well as his gender domination as a husband to silence her, to send her to her room, giving her "time out and sanction." In this husband-wife "battle," Stella has to confront both gender and class subordination simultaneously. This dual subordination can also be seen in her class and gender identities. Her husband's family name, Gregory, is mentioned to identify both his class and possession, whereas Stella's maiden name is absent from the reference. Her proletariat family name is not identified, and she is rendered into the daughter of the unnamed workingman.

In its further course, the conflict between Stella and Arnold ceases to be the couple's quarrel, family dispute, nor individual's disagreement; instead, it turns into "class warfare." This class war is displayed through Stella's psychological and physical identification with the working class as "one united" group that she defends against Arnold's disgust with the strikers. The anonymity of Stella's paternal name suggests her "body and soul" affiliation not only with her proletariat father but also with the working class in general. The repeated mentioning of the fishermen who have difficulties in pulling the fish from Arnold's lake for their supper and her concerns toward their plight show this strong bond between Stella and her inherited proletariat class root.

All morning she had looked, from time to time, at the fishermen sitting quite still on the glassy lake and not once had they pulled a fish ... It seemed to her, in half drowse, that the fishermen far down below must be pulling in fish when she wasn't looking. Arnold had everything, he certainly would have fish in his lake ... Yes, she thought, I've married above me. Those fishermen can't be really fishing, it's all part of the game. "Won't they catch anything?" she said. (Le Sueur 27, 31, 33) 
In addition to this fishermen reference, Stella's political and class side can also be seen in her preoccupation with her father-in-law's old wine cart that he brought from Sicily, Italy. She loves the painted works in his wine cart, depicting the daily life of the working class (women, men, babies) in a rural Italian vineyard.

She had to get out of the house, so she went down towards the old wine cart which she loved. Every little man so gaily painted on it reminded her of her own father . . . everywhere were the faces of men like her father's-ancient, long, forgotten workmen picking grapes, carving, hammering, carrying faggots ... (Le Sueur 29)

Her empathy is strong for these people; again and again, she sees them as "the one and the same group" belonging to her father's social class, the unified group bound by "the same" domination and oppression. Her emotional bond toward the working class is finally manifested into a physical association and preference. Stella views the working class as a singular and homogeneous group under the same plight. Furthermore, she also sees their "body" as one and the same:

the workman's body like her father's. The body of a workman was the same everywhere ... the same sensitive body moulded close its labor, a worn tool. (Le Sueur 29)

Similarly, she also identifies her husband's body with his class representation:

Why had Arnold's body been distasteful to her, his white hands, his white narrow chest, self-conscious, without use .. . Making money never made a use of a man's body, the smell of it got on him. Perhaps a woman never really could love the body of a moneymaking man. Could it be true? She put her hand down on the burning wood of the wine cart and cried. (Le Sueur 3o)

Her repugnance of Arnold's body is no longer based on marital relation, but is strongly established through class relation and difference. This "body-class" association is indeed very interesting because Le Sueur's text actually reverses the dominant stereotypes about the working class. Even the middle class attempt to separate themselves from the working class not only by their different accumulated wealth but also by their different perspectives of

good and evil, of pleasant and unpleasant, of funny and serious, of beautiful and ugly ... of taste in books and food and clothes, table manners, turns of speech, accent and movements of the body. (Orwell 114 and 149; Day 172).

Moreover, Orwell also suggests that "the middle class view that the lower classes smell" creates wider and deeper divisions and barriers. Accordingly, their middleclass cultural taste and sensibility also perceive "something subtly repulsive about 
the working-class body" (Orwell 119-120; Day 172). Le Sueur's text presents the reversal of this body association and affiliation between Arnold, the capitalist and the workingmen, the proletariat. In addition to bodily odor, her short story employs skin and body complexion in their class difference in term of power and labor.

All morning she had looked, from time to time, at the fishermen sitting quite still on the gassy lake and not once had they pulled a fish. They looked burned to a char with their black poles out over shimmering water. (Le Sueur 27)

Why had Arnold's body been distasteful to her, his white hands, his white narrow chest, self-conscious, without use. Making money never made a use of a man's body, the smell of it got on him. Perhaps a woman never really could love the body of a moneymaking man. (Le Sueur 30)

Why had she given up her many hungers for this? "You ..." she cried in contempt knowing his pale body as if it had been dead under water. (Le Sueur 36)

Le Sueur's reversal of body-class association and affiliation privileges the working class and relegates the capitalist into an inferior position. The use of "burned" and "char" for the fishermen is appropriate in this case rather than "tan" or "tanned" as a choice of words because the former suggests a degree of intense labor under the sun exposure; meanwhile, the latter, connotes a possibility of sun exposure during leisure or vacation. The fishermen fish for their supper and not exercise fishing as a game and sport. Whereas, the diction of "white" and "pale" for Arnold suggests the absence of intense physical labor.

Interestingly, despite her love for the working-class body, Stella also views them as physically "passive" for they are only in the "waiting mode" hoping to catch fish: "fishermen sitting quite still on the gassy lake and not once had they pulled a fish" (Le Sueur 27). On the other hand, she is depicted as mentally and verbally active, always thinking about their plight, willing to defend them. The proletariat has Stella as their advocate, while Arnold the capitalist has the policemen on his side to protect his class interests and hegemony.

"We'll show them who is the head of this country... They probably brought in a lot of thugs from Chicago, beat up the policemen in the performance of their duty, to protect life and property ..."

She said to him, jeering, "Are you really going down there tomorrow, all you businessmen to fight the strikers?"

"Yes," he said, "We are."

Kritika Kultura 35 (2020): 57-071

(C) Ateneo de Manila University

<http://journals.ateneo.edu/ojs/kk/> 
“Then you'll get hurt," she said with satisfaction. (Le Sueur 33-6)

In her struggle to fight for working-class interests, Stella becomes the voice of the proletariat against her husband's capitalist rule, and in this matter, the class and gender relations are intricate and conflicting. On the one hand, she is "inferior" to her husband's position in terms of gender and class relations: she experiences both gender and class subordination under her husband's patriarchal and capitalistic rules. On the other hand, she has more material privilege of wealthier class members than those fishermen who have to struggle with their hunger and poverty; she also sees herself as "superior," as a woman to those fishermen, the proletariat. Her gender superiority can be seen in her ability to actively think and speak for them in contrast with their passivity and silence. In her helplessness to fight Arnold's power, she visualizes and imagines her active roles not only as the voice of her paternal class group but also as their "leader and savior" that would lead them to a revolutionary struggle to destroy Arnold's dominance.

The complexity of class and gender relation is also problematized further by the presence of Henrietta, her housekeeper. Similar to the fishermen depiction, she is portrayed as a silent but observant woman, constantly listening and watching every move in her master/mistress's house. Her silence, however, is also "subversive" because it evokes numerous invisible obstacles and divisions of gender and class interplay. While Stella's affiliation with the working class does its share of problematizing class and class-consciousness identities, it is plain and simple that Henrietta's side is on her proletariat fellows, for she herself is of the lowest rank of their gender and class hierarchy. Further complication of class and gender interplay is displayed through Stella and Henrietta's relation. In the past both women shared the same gender and class affiliation, but Stella's upward class mobility has separated their class bond and created another hierarchical relation of class and gender. They are no longer "proletariat sisters," but "master and servant." This new relation creates tensions and prejudice between them, constantly spying on one another, just like the way Stella spies and is on guard all the time toward Arnold. Stella easily affiliates herself with the working class outside her house, but she cannot do the same with Henrietta, the member of the same class that Stella passionately defends. She views Arnold as an evil master to his workers, but she refuses to see herself that way to Henrietta who works for her in her house, performing Stella's domestic duties and gender roles. Her denial shows that her interests are "just" while Arnold's are "unjust." While oppressing Henrietta, she simultaneously parades herself as the benevolent advocate and savior of the working class. Both women experience the simultaneity of subjugations, but they cannot unite themselves by gender nor class bond. This contradictory and conflicting relation also informs wider divides in each class division. 
The working class is also classified according to their gender roles and spheres like the depiction of working class life on the Gregory's wine cart: "ancient, long, forgotten workmen picking grapes, carving, hammering, carrying faggots, and women nursing babies, cooking, bending, lifting" (Le Sueur 29). Henrietta, as the working class woman, also follows her gender roles and spheres, but performs those traditional gender rules in the house of the capitalist family outside her own domestic sphere. In her case, her paid work is also her designated private gender space, although of other people's family. Trespassing these gender spheres and boundaries would often violate the ideological difference between family/paid work and private/public as seen in Arnold's repugnance of seeing women and young girls joining the strike on the street, challenging both capitalist and patriarchal rules and sanctions.

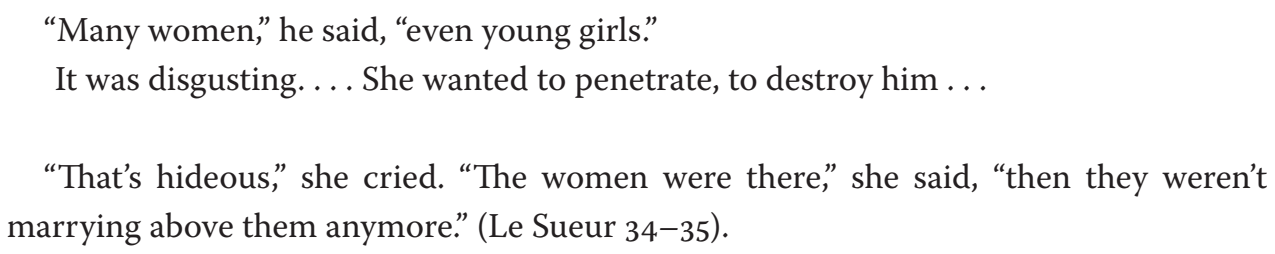

Stella also attempts to struggle against her husband's patriarchal and capitalist power. Unlike the women and girls who participated in the strike in public, she can only contest her husband's rule over both private and public spheres inside their own family. Her disinterest in performing her wifely and motherly duties is one of her rebellious ways to contest her gender roles: "Get whatever you want for supper, Henrietta, I don't care what it is, and I don't want to take the baby out this afternoon." (Le Sueur 28). Stella finally views her marriage to Arnold and her reproductive role to continue his patrilineal line as humiliation and defeat of her paternal class.

Why had she given up her many hungers for this? "You ..." she cried in contempt knowing his pale body as if it had been dead under water and she shook with humiliation and grief to know how she had been with him, borne him a child. "You're through," she cried, "you're through, there's no wine in your cart!"

The fishermen started to row towards shore.

"Stella," he said, shaking her. (Le Sueur 36)

Driven by her frustration, she envisions the defeat and the destruction of her capitalist husband by imagining the workman figures of the wine cart multiplied and rising up (Le Sueur 35-6). Her repeated exclamation of his destruction is finally negated by the use of "can" as the modal verb to signify Arnold's "ability 
to die": "You'll get hurt,' she said and she thought, 'I hope he is killed. I hope he can die!"' (37). Everyone will finally die, but Stella can only wish that her husband "can" indeed die, referring to his patriarchal and capitalist stronghold of power over her gender and class at the end of the story. The complexity and heterogeneity of class and gender relation in Le Sueur's "No Wine in His Cart" is problematized further in Suchen Christine Lim's's Fistful of Colours with ethnicity impacting on the category of the "family."

\section{GENDER WAR AND CLASS STRUGGLE IN LIM'S FISTFUL OF COLOURS}

Born in Ipoh, Malaysia in 1948, Lim moved to Singapore when she was only 14 years old. Both Malaysia and Singapore become frequent backgrounds in her works. She is now one of the most prominent Malaysian-Singaporean authors. She has received several awards for her works such as the Singapore Literature Prize and Southeast Asia Write Award. Among her famous works are The Lies That Build A Marriage (2008), Fistful of Colour (2003), A Bit of Earth (2001), and Rice Bowl (1984).

Similar to "No Wine in His Cart," gender and class relations in Fistful of Colour (2003) is also portrayed within "family." Unlike the marriage of proletariat wife and bourgeois husband of Stella and Arnold, the wife-husband class relation in Fistful of Colours is reversed. The wife is Madam Geok Neo, the daughter of Towkay Ong, a wealthy Baba or Peranakan Chinese (a Chinese person who was born and resides in Southeast Asia) and the husband is a China-born poor man, Lim Ah Buck, a rickshaw puller and coolie in the colonial Singapore. Intermarriages between people of different class and gender often happen; however, Madame Geok Neo and Ah Buck's marital union is extraordinary not only because class and language difference (as a Nonya/Peranakan or hybrid Chinese, Madame Geok Neo speaks Hokkien and Malay while Ah Buck speaks Mandarin), but it also involves Chinese traditional culture of adoption. There are two kinds of son adoption in Chinese culture: one is from the same family surname and the other is from a different surname. Towkay Ong cannot provide a biological son to continue his paternal line; therefore, to solve the absence of the male heir in the family, he practices "a chewkia-sai son-in-law" adoption of the Hokkien community-to invite a man to marry into the family and swear to give their firstborn son the surname of the father-inlaw. This particular adoption practice is very rare because of the importance of the surname and ancestor worship for the Chinese family. It is almost "impossible" to think of a Chinese man who would do such "unfilial conduct," that is, giving up his surname. However, driven by poverty, Lim Ah Buck does not only agree to be a chew-kia-sai son-in-law, but also to change his surname, Lim, to his father-in-law's

Kritika Kultura 35 (2020): 60-071

(C) Ateneo de Manila University

$<$ http://journals.ateneo.edu/ojs/kk/> 
surname, Ong. After his father-in-law dies, Lim Ah Buck also inherits his class title, Towkay Ong, and all the family wealth. After Ah Buck becomes a rich and successful towkay, he does finally resume his filial responsibility and duty to his own patrilineal line of the Lims by reinstating their memorial tablets side by side with the Ongs in their family altar, although not without resentment from his wife, the Ong daughter.

In general, the ancestor tablet or/and ancestral hall in the Chinese house functions as one of the markers of "being Chinese," and by performing the proper rituals and propriety such as ancestor worship and filial piety, a member of the Chinese community would acquire this stage of "being properly Chinese"; thus, being civilized as expressed by the Lim/Ong daughter in law.

\footnotetext{
"It was passed down from my mother-in-law. Her mother gave it to her, ah. And she gave it to me, mah!" her mother had once explained to a friend in her affected Hong Kong-accented Cantonese which she had acquired as part of her upward mobility. "My mother-in-law was the daughter of a small mandarin in China. Not a very important judge," her mother continued modestly, "but still a kind of scholar, mah. And their family brought out this rosewood altar when she married our patriarch. To put her ancestors' memorial tablets, ah! Aiyah, where can you find such filial children nowadays? Young people are so different now." (Lim 34)
}

In presenting the family altar, she also recreates Lim Ah Buck's class roots as the poor coolie into a wealthy businessman. This family altar and the memorial tablets are not only a sign of filial piety, but also a display of family social class as well; thus, it shows the merging and blurring of private-public gaze of the family story and history.

Another example of the practice of rituals and ancestor worship to show filial piety and the merging and blurring of private-public space and gaze is the funeral ceremony. In this funeral ceremony, the family may hold a grand funeral for their parents. As such, they show (in a literal and symbolical display) this filial piety publicly and at the same time, display the family's wealth and social class status. As expressed in the opinion that "through family rituals, such as mourning for deceased parents and providing splendid funeral ceremonies, sons demonstrated to the public their filial piety" (Ikels 21). This "family" practice and rituals to continuously perform "familyness" and being "family" and in the "family" is also in accordance with the aforementioned connection and modification of Foucauldian discursive theory, Butler's performative theory, and John Ganon and William Simon's "socially scripted behaviour." Gagnon and Simon are sociologists who wrote several books on sexuality and sexual conducts and view them as a "socially organized script" in relation to the complexity of culture, economic, psychology, 
and other social aspects. Thus, in many ways their theoretical views are in line with those of Butler, Mills, and Foucault in terms of discourse, performativity, social practices, and power relation. Gillian Dunne published many articles on gender and sexuality, particularly focusing on lesbian and queer theories. Because "family" as a discursive construct needs to be repeatedly performed, therefore, according to Dunne (1999), it implicitly also needs an audience. As such, practices such as family rituals-weddings, christenings, family-based religious festivals, and touring holidays - can be considered as a family's staged performance. Deborah Chambers is a professor of Media and Cultural Studies at the Newcastle University, she has written some books on the sociology of the family and one of them is Representing the Family (2001) used in this article. Elaborating on Dunne's argument, Chambers considers that:

Family photography, the family album and home video are powerful ways in which these rituals are captured and framed so as to offer families an audience, a kind of private/ public gaze that surveys and monitors the parameters and success of the performance. (29)

Chambers also argues that the family photograph album "offers a powerful ideological device for the continuous reinvention and re-presentation of familyness" (29). The continuous production and operation of "family" as the discursive construct will in effect make it "natural." Following Butler's concept, this kind of discourse is a performance that has its conventions. From this standpoint, the theories of Butler and the feminist appropriation of Foucauldian discursive notion by Mills are indeed important in this study of "family."

Fistful of Colours also presents another class upward mobility through marriage as seen in the marriage of Ah Buck to his second wife, Ah Chun (Sia Liew). This marriage and class upward mobility is also conducted and performed through a series of proper rituals and ceremonies to mark the acceptance of this union legally and culturally into the Chinese "family." Before becoming his wife, she is only a servant girl brought by Ah Buck for his wife, Geok Neo, as a gift after having finally succeeded in having a son for the Ongs. This second wedding is simple compared to the first one not only because of class differences, but also of the concubine status tradition. As a servant "favored and chosen and raised" to be a concubine, Ah Chun undergoes a particular ceremonial wedding ritual to be a "char-boh-kan," a servant-concubine chosen by the first wife for her husband. It is just a simple wedding with only members of the family as witnesses and guests. Ah Chun has to walk from the back door to the front gate carrying a bucket of water in each of her shoulders as dictated by the rules for the bondmaid or concubine's wedding ritual to remind her of her lower status, that is, slightly higher than the servants but lower 
than that of the children in the family. In this ritual, her class upward mobility is also marked by her new name.

Ah Chung's simple wedding with its humiliating ritual to fit her low social status is in contrast to the elaborate and festive wedding ceremony of Geok Neo and Ah Buck that also displays the high social class status of Geok Neo, Ah Buck's first wife. Furthermore, Geok Neo's wedding ceremony also demonstrates her social status, as seen through the gold-and-jade pin in her hair, in contrast to Ah Chun's simple hairstyle. This extravagant bridal hairstyle is performed through an elaborate combing ritual; however, this display of the bride's high social class status also becomes the discursive site of her gender roles and oppression in the family as dictated by the chants sung throughout the combing ritual. The wedding ceremony of Ah Buck and Geok Neo follows the traditional Chinese ritual. First, the bride kneels in front of the altar, presenting tea and wine offerings to the gods and ancestors. Then, she kowtows three times, knocking her head upon the wooden floor, and undergoes the traditional Cantonese bridal maiden hair-brushing. While combing and styling her hair, the female elders in her family "pour out more libations of tea and wine for the God of the Earth and the Goddess of Fertility." They chant these words of advice as described in the novel (Lim 42):

Bow to heaven and pray to the gods.

Pain, aye, pain is the woman's lot.

Pain goes with her when she leaves her mother's side;

Pain lies with her when she lies in bed each night.

Pain is with her when she carries her child;

Pain is with her when she is without child.

Aye, Geok Neo, may the gods bless you with sons!

Sons aplenty like the seeds of the pomegranate.

May you sow his seeds and reap his sons,

Else you lie with pain and he lies with another one.

In their chants, the women do share their painful experience as a wife and mother with or without children; however, at the same time, they do extend their good wishes for the bride to have not only progeny, but most importantly male offspring.

Those chants by the elder women point out "the woman's lot" of leaving her biological family to enter into her husband's family and perform her specifically expected gender role, to produce a male heir to continue her husband's patriline. Their chants repeatedly emphasize the word "pain" as a consequence of performing this reproductive role, being a wife, and the possibility of another woman taking her role if the bride/wife fails to fulfill her familial duties. 
Similar to Geok Neo's extravagant wedding ritual as an official initiation for the bride to enter and pledge her submission into the formal space of Chinese patriarchal family to fulfill her gender roles, Ah Chun's simple wedding ritual also marks her submission to both her class and gender roles in the same family. As a bondmaid without any family members of her own, it is only the old servant from the Ongs who performs the simple hair combing ritual for Ah Chun. The old servant is the one who performs the hair brushing. Unfortunately, the old amah, who had never been married before, did not know the ritual song well enough. As a substitute, she adjusts the chants to into a disjointed fragment in Cantonese. As the Old Amah chants her wish to the bride:

Aye, comb your hair. May you grow white and old. Comb your hair again. The gods bless you with sons and gold. And, aye! The gods bless you, Ah Chun. From today, your life will be different. You are going to be a married woman. Wear this rose and jasmine. They will have to do in place of a gold hairpin, ah! (Lim 56)

It is just a simple wedding with only members of the family as witnesses and guests, yet it similarly functions as a performative ritual to initialize and formalize her gender and class submissions into the Chinese patriarchal family. In addition to this specific and humiliating ritual for the bondmaid's wedding, Ah Chun performs the worship in front of the altar and the wine-tea offerings to the gods and ancestors. She also has to do the same offering to her mistress (Geok Neo) and her master-husband, Ah Buck. The novel describes:

Ah Chun knelt down before them and kowtowed three times ... Then Geok Neo took out an embroidered slipper and hit her three times on the head. "Hitting you is reminding you who you should obey. Under my hand and under my feet, you are the concubine today. Serve your master and serve me well," Geok Neo chanted in Hokkien.

"I name you Sia Liew the pomegranate. Be fruitful and bear us sons." (Lim 57-8)

This wedding ceremony signifies the double burdens of bondmaid-concubine to serve both the mistress and the master. The naming act of her by Geok Neo and the insistence on her reproductive role signify ownership and control of Ah Chun (Sia Liew), of her total personhood.

Traditionally, all children that the bondmaid-concubine would have in the family would legally and culturally belong to the first wife even though this bondmaidconcubine is the biological mother of those children, such as shown in the life experience of Ah Chun as a bondmaid-concubine. In such case and perspective, the definition of Chinese motherhood is distinguished from the Western concept of motherhood. 
Ah Chun (Sia Liew)'s life is indeed painful; however, fate dictates a different future for her. At the end she dies as a rich and successful businesswoman with a grand funeral held by her filial son, in contrast to the simple funeral of Geok Neo and Ah Buck. The novel describes:

Ong Tay Luck gave his mother one of the biggest and grandest funerals the Chinese community there had ever seen. It was an event remembered for years. More so because, and precisely because, his mother, Sia Liew, was a former bondmaid and concubine. Bondmaids were not entitled, at least in the old days, to grandeur of any kind. (Lim 162)

The patriline dictates many aspects of family rituals such as weddings, mournings, ancestor worship, and observes the strict practice of the gender rule to ensure the survival and continuity of the patriline from generation to generation that link the Chinese family to their members in life and the afterlife. However, there are some changes and continuities of those practices.

Family photos and photo albums display these differences of ethnic portrayals and class mobility in the family from generation to generation, witnessing the family stories and histories as well as the nation's stories and histories. Their private family stories and histories are juxtaposed with their family's present conditions as well as the shift of political power in Singaporean history. As such, family photos can become the witness of these stories and histories through their private-public gaze and sphere; however, family photos can also both reveal and conceal these stories and histories to follow the intentions of the family or the nation in their portrayal and representation of themselves to the family, as well as the public, as shown in the selection of family photos by Yoke, Ah Chun/Sia Liew's daughter-inlaw, in their family photo album collection. Yoke does not display all their family photos in their family photo album; she discards the pictures of her father-in-law as a poor coolie in the past; instead she displays his pictures as their patriarch, a successful businessman and respected man in their society to their family guests. Yoke explains:

"Over here is our patriarch, the second towkay, Ong Ah Buck. My husband's father. He was very respected by the British in his days, ah! First Chinese to start a bus company here." . . . Albums of photographs kept in dusty drawers and forgotten told a different story ... The Story Behind The Photographs: How Ong Ah Buck The Rickshaw Puller Became The Rickshaw Owner . . . There was a black-and-white photograph of sullen rickshaw pullers and their rickshaws parked in front of a shophouse in Pagoda Lane. It was the only photograph in the Ong family album which showed its patriarch as a lean hungry-looking man eking out a living as rickshaw coolie. What the photograph did not show was daily life in Chinatown; what it was like to live in a dunghole in the early nineteen hundreds. (Lim 34-5) 
The patriarch of the family is presented as a respectable man in the society of both the Chinese community and the English social circle to represent the family's wealth and social class. Meanwhile, the life story of the patriarch as a poor rickshaw puller and coolie is hidden and not acknowledged; this poor past of the patriarch instead is replaced by the "fabricated" respectable family lineage of the judge in China of his wife's patrilineal side as told by Yoke to their guests. Deborah Chambers calls such an inclusion-and-exclusion process of selecting pictures for and from the family photo album with its viewing and storytelling acts as "representing the family by the family":

Family photography and family albums are powerful tools of cultural representation enabling individual families to narrativise their sense of unity, heritage, intimacy and spatial belonging. As such, the humble family album became a sophisticated ideological device. It authenticated and celebrated public discourses of familial heritage, blood ties, continuity and connection within a private cultural form that also articulates emotions of intimacy, security and belonging. It performed the crucial role of transforming the experience of nuclearized parenthood into a spectacle ... Viewing albums requires a ritualized oral dialogue of description, storytelling, memory-making, nostalgia and celebration as well as denial, absences and secrecy. (Chambers 75-6)

Furthermore, women like Yoke play an important role in this representation and reinvention of the "family" by the family because the family photo album is considered to be "a predominantly feminine cultural form" as a visual medium for family genealogy and storytelling shaped by women. Therefore, women take their role as "the keeper of the past" despite their absence and exclusion from "the public narratives of history, they have been present in private narratives: in the context of compiling albums as celebratory, memorialized and nostalgic representations of parenthood and childhood" (Chambers 77). The family photo albums, therefore, are used to conceal the family past (stories and histories) as well as to re-create and re-present the family past and present histories. The Ong family photos also uncover the life stories of Sia Liew, Yoke's mother-in-law in the Ong family history. The novel describes:

The baby's mother, Madam Sia Liew, was staring out of the photograph. She looked young and nervous. Her hands clutched the armrests of the rosewood chair. On each wrist was a thick gold bangle. And at her feet was a porcelain spittoon with a floral pattern, the symbol of wealth among the Southeast Asian Chinese at the turn of the century ... The camera had frozen for posterity the image of a young woman from a well-to-do family, giving one the impression that she could be the daughter of a rich towkay. (Lim 202)

Kritika Kultura 35 (2020): 66-071

(C) Ateneo de Manila University

<http://journals.ateneo.edu/ojs/kk/> 
The photo depicts Sia Liew as a young rich woman (mother) of a wealthy Chinese family in Southeast Asia as indicated by her gold bangle and the rosewood chair and a porcelain spittoon in the background/foreground of the picture.

However, Sia Liew's entry into the Ong family is not as "respectable and rich" as the picture depicted; she had to endure long and frequent humiliations and suffering as a bondmaid and a concubine in the Ong family before eventually being accepted as "equal" member of the family as shown by two different family photo sessions. The novel describes:

"You look at these two photographs. Look." The first one showed Madam Geok Neo's jowly face marred by her harelip. But, nevertheless, she looked resplendent in her silk embroidered jacket and skirt of black silk, her bound feet shod in embroidered shoes. Her hair was immaculately coiffured and decorated with jade and gold hairpins. She sat on a rosewood chair with hands resting on her lap, exhibiting the jade and diamond rings and her jade and gold bracelets. Standing beside her seated figure was Madam Sia Liew in a simple floral samfoo, looking like a plain countrywoman.

The second photograph showed a dramatic change. Madam Geok Neo and Madam Sia Liew were both seated on rosewood chairs like sisters or equals. And what was even more conspicuous was the similarity in their dressing. Both wore the traditional silk samfoo jacket and ankle-length black skirt of Chinse gentlewomen living in China, just before World War II. Suwen noticed that they were even wearing the same number of pearl and diamond necklaces, jade bangles and diamond rings. But Madam Geok Neo's thickset figure looked as if it was suffering from gout and was too heavy to get up without help. Her eyes looked out of the photograph without lustre, staring blankly at a point beyond camera. In contrast, Madam Sia Liew Looked radiant. She had blossomed into a buxom matron. (Lim 217)

The first and second family photos show a contrast of Sia Liew's portrayal and status in the family. She is given the similar privileges of dresses and jewelry as the first wife only after she gives birth to a son and helps solve her master-husband's financial family troubles. The family photos display her struggle and rise as a bondmaid and concubine into an "equal" member of the Ong family despite the permanent mark of different class status displayed by Geok Neo's bound feet.

Similarly, family photos can also display the status and existence of members of the family as exemplified by Sia Liew's presence in the Ong family photos from time to time, as well as to include or exclude the family members' presence as shown by the photo of Ong Ah Buck with his children:

There was one photograph of Ong Ah Buck and his four "official" sons. These were the three sons from his marriage to Madam Geok Neo and the son of his concubine. 
The photograph showed Towkay Ong dressed in a Western suit with bow tie and black leather shoes, looking like an English-educated Baba gentleman entering the world of modern business and industry. He had grown stout and portly with hair thinning at the crown. Madam Geok Neo's three sons stood in a row behind their father. The eldest, Ong Tay Ik, wearing thick glasses, was the scholar in the family and the apple of his mother's eye; son number two, Ong Tay Yee, would soon be a trader, wheeling and dealing in the far-flung islands of Indonesia; son number three, Ong Tay Sah, became the family's tinker and repairman. And finally, there was son number six, Ong Tay Luck, the young son of Sia Liew who stood beside his father. (Lim 216)

In the picture the wealthy and successful Ong Ah Buck (initially a China-born poor and illiterate rickshaw coolie) is presented and re-presented as the modern Peranakan Chinese with the English education status symbol and his four "official" sons; however, he actually has six sons but because of the "illegitimate" status of the other two, they are not presented and re-presented in their "official family photo." Thus, the presence of family members in their family photo album also legitimizes their family membership status as well.

Those different constructions of Chinese Singaporean identities are not always harmonious and well-accepted in the world of differences in the multiculturalethnic-linguistic-education-politics-generation of Singaporean society. The colorful arrays of these differences also bring conflicts and painful struggles in the past and in the present-day Singapore, and Lim symbolically has fittingly depicted in the title of her novel as a "fistful of colours": full of conflicting struggles if confronted openly, yet may also gain a degree of success with an earnest effort to make it work, and finally make a good fist of it.

\section{CONCLUSION}

There are some similarities and differences between Le Sueur's "No Wine in His Cart" and Lim's Fistful of Colours in the way both writers express the gender and class struggles in the family. Le Sueur focuses more on gender and class struggles in the Western family to illustrate how the wife-husband and employer-housekeeper relations represent the larger gender and class struggles in the Western capitalist society. The stories of women characters of different social classes inside the family such as Henrietta and Stella, as well as those women workers outside the home demonstrating against their capitalist employers, are given more voice and articulation to prioritize their experiences and lives through women's eyes. However, the ending of the story offers a pessimistic tone and almost an impossible space for women to liberate themselves from the oppressive patriarchal and capitalist family 
and society. Meanwhile, Lim's Fistful of Colours narrates the stories of Ah Buck's wives, Geok Neo and Ah Chun/Sia Liew, and their family practices that reflect the diversity of Chinese family practices in terms of class and gender from generation to generation, which also become the extension of the stories and histories of Singapore as a nation. Although frequently the Chinese patriarchal family is seen as more traditional and oppressive compared to its Western counterparts, Lim maintains to provide a space for the women characters in her novel to negotiate the class and gender relations in their family, and even offers a possibility of a "happy ending" for the women characters in contrast to Le Sueur's oppressed women characters.

Furthermore, both Le Sueur and Lim also problematize the notion and intersection of class and gender in the family by employing the short story and the novel as their narrative/textual/political/ideological strategies to facilitate and articulate the voices and lives of marginalized groups in terms of gender and class relations. Le Sueur's "No Wine in His Cart" presents the complexity of theorizing gender and class relations. The dynamics and the instability of gender and class identities are displayed to reveal how both gender and class inform one another in each specific context with heterogeneity and fluidity. Similarly, Lim's Fistful of Colours unveils that there is not one Chinese identity in the Southeast Asian ethnic Chinese family; they are many and heterogeneous. Lim's novel displays features of hybridity versus purity, differences versus identity, and mobility versus stasis as well as the blurring and the merger of private-public gaze and sphere of the family as exemplified in performing family rituals such as wedding and funeral rituals, and other modern family rituals such as family photo albums.

This poststructural perspective of socialist feminisms problematizes and challenges the notion of class and gender and challenges the private-public spheres of "family" stories and histories of the diverse and heterogeneous American society and its Southeast Asian counterpart. This brief article also presents the key argument that "family" and its discourse play a significant role as an arena of gender and class struggles both in the East and the West. 


\section{Works Cited}

Acker, Joan. "Hierarchies, Jobs, Bodies: A Theory of Gendered Organizations." Gender E Society, vol. 4, 1990, pp. 139-158.

Bakhtin, Mikhail Miklailovich. The Dialogic Imagination: Four Essays. Edited by Michael Holquist and translated by Caryl Emerson and Michael Holquist, U of Texas P, 1981.

Barlow, Tani E. The Question of Women in Chinese Feminism. Duke UP, 2004.

Butler, Judith. Gender Trouble: Feminism and the Subversion of Identity. Routledge, 1990.

Cameron, Deborah. "The Language-Gender Interface: Challenging Co-Optation." Rethinking Language and Gender Research: Theory and Practice, edited by Victoria Bergvall et al., Longman, 1996, pp. 31-53.

-.. "Performing Gender Identity: Young Men's Talk and the Construction of Heterosexual Masculinity." Language and Masculinity, edited by Sally A. Johnson and Ulrike Hanna Meinhof, Blackwell, 1997, pp. 47-64.

Carsten, Janet. After Kinship. Cambridge UP, 2005.

--, ed. Cultures of Relatedness: New Approaches to the Study of Kinship. Cambridge UP, 2000.

Chambers, Deborah. Representing the Family. Sage, 2001.

--. "The Confucian Conception of Gender in the Twenty-First Century." Confucianism for the Modern World, edited by Daniel A. Bell and Chaibong Hahm, Cambridge UP, 2003.

Cohen, Myron L. Kinship, Contract, Community, and State. Stanford UP, 2005.

Day, Gary. Class. Routledge, 2001.

Donovan, Josephine. Women and the Rise of the Novel, 1405-1726. Macmillan, 1999.

Doody, Margaret Anne. The True Story of the Novel. Rutgers UP, 1996.

Dunne, Gillian A. "A Passion for Sameness?” The New Family?, edited by Elizabeth Bortolaia Silva and C. Smart, Sage, 1999.

Engels, Frederick. The Origin of the Family, Private Property and the State in the Light of the Researches of Lewis H. Morgan. Translated by Alick West, International Pub., 1942.

Eshleman, J. Ross. The Family: An Introduction. Allyn and Bacon, 1994.

Evans, Grant. Asia's Cultural Mosaic: An Anthropological Introduction. Prentice Hall, 1993.

Foucault, M. The History of Sexuality, Vol. 1: An Introduction. Translated by Robert Hurley, vol. 1., Penguin, 1978.

-.. Power/Knowledge. Harvester, 1980.

Gagnon, John, and William Simon. Sexual Conduct: The Social Sources of Human Sexuality. Aldine, 1973.

Gould, Carol C., editor. Gender: Key Concepts in Critical Theory. Humanity Books, 1997.

Gu, Ming Dong. Chinese Theories of Fiction: A Non-Western Narrative System. State U of New York, 2006.

Hartmann, Heidi. "The Family as the Locus of Gender, Class, and Political Struggle: The Example of Housework." Feminism and Methodology, edited by Sandra Harding, Indiana UP, 1987.

Kritika Kultura 35 (2020): 70-071

(C) Ateneo de Manila University

<http://journals.ateneo.edu/ojs/kk/> 
--. "The Unhappy Marriage of Marxism and Feminism: Towards a More Progressive Union." Women and Revolution: A Discussion of Unhappy Marriage of Marxism and Feminism, edited by Lydia Sargent, South End P, 1981.

Ikels, Charlotte, editor. Filial Piety: Practice and Discourse in Contemporary East Asia. Stanford UP, 2004.

King, Victor T., and William D. Wilder, editors. The Modern Anthropology of South-East Asia: An Introduction. Routledge, 2003.

Lang, Olga. Chinese Family and Society. Yale UP, 1976.

Lauret, Maria. Liberating Literature: Feminist Fiction in America. Routledge, 1994.

Legge, James, translator. Classic of Filial Piety: Sacred Books of the East. Oxford, 1879. Le Sueur, Meridel. "No Wine in His Cart." Salute to Spring. International Pub., 1989.

Lim, Suchen Christine. A Fistful of Colours. SNP, 2003.

MacKinnon, Catharine A. "Feminism, Marxism, Method, and the State: Toward Feminist Jurisprudence." Feminism and Methodology, edited by Sandra Harding, Indiana UP, 1987.

McDowell, Linda, and Rosemary Pringle, editors. Defining Women: Social Institutions and Gender Divisions. The Open U, 1996.

Milner, Andrew. Class. Sage, 1999.

Mills, Sara. Discourse. Routledge, 2005.

Ollenburger, Jane C., and Helen A. Moore. A Sociology of Women: The Intersection of Patriarchy, Capitalism, and Colonization. Prentice Hall, 1992.

Orwell, George. The Road to Wigan Pier. 1937. Penguin, 1989.

Poe, Edgar Allan. "The Importance of the Single Effect in a Prose Tale." The Story and Its Writer: An Introduction to Short Fiction, edited by Ann Charters, St. Martin's, 2003.

Pollert, Anna. "Gender and Class Revisited; the Poverty of 'Patriarchy."' Sociology, vol. 30, 1996, pp. 639-659.

Reynier, Christine. "Theorizing the Modernist Short Story with Woolf (and Agamben) as an Art of Empowering 'Poverty." Journal of the Short Story in English, Spring 2015, p. 6.

Robinson, Lillian S. Sex, Class, E Culture. Methuen, 1978.

Sargent, Lydia, editor. Women and Revolution: A Discussion of the Unhappy Marriage of Marxism and Feminism. Pluto, 1981.

Stacey, Judith. Patriarchy and Socialist Revolution in China. U of California P, 1983.

Waltner, Ann. "Kinship Between the Lines: The Patriline, the Concubine and the Adopted Son in Late Imperial China." The Modern Anthropology of South-East Asia: An Introduction, edited by Victor King and William D. Wilder, Routledge, 2003, pp. 67-8o.

Zang, Xiaowei. "Family, Kinship, Marriage and Sexuality." Understanding Contemporary China, 3rd ed., edited by Robert E. Ganer, Lynne Rienner Pub., 2008, pp. 281-307. 